\title{
1999 BERKSHIRE CONFERENCE ON THE HISTORY OF WOMEN
}

\section{CALL FOR PAPERS}

The 11th Berkshire Conference on the History of Women, "Breaking Boundaries, "wili be held on June 4-6, 1999 at the University of Rochester, Rochester, New York USA. The Program Committee welcomes proposals that transcend regional, disciplinary, and cultural boundaries; that break traditional boundaries of academic presentation and explore innovative ways of presenting material and involving the audience. The Committee also seeks proposals that discuss pedagogy, public history, collaborative research, and feminist activism. The Committee encourages international participation and panels that represent a diversity of participants.

We prefer proposals for complete panels (normally two papers, one commentator, and a chair) or roundtables, especially those with cross-national and comparative themes. Individual papers will also be considered. The Program Committee may rearrange panels; submission of a proposal will be taken as agreement with this proviso. No one may appear more than once on the program in any capacity.

Please submit proposals in triplicate, postmarked by January 31, 1998, in a single packet marked "ATTN: Berkshire Conference" to the appropriate co-chair. Each proposal must include: 1) panel title or roundtable theme; 2) title and one-page abstract of each paper or presentation; 3) name and address of contact person; 4) one-page vita for each participant, including current address, telephone number, fax number, and e-mail address; 5) a self-addressed, stamped postcard for return upon receipt of packet.

Send proposals on U.S. and Canadian topics to Nell Painter, Department of History, Princeton University, Princeton NJ 08544-1017; on European topics to Sharon Strocchia, Department of History, Emory University, Atlanta GA 30322; on Africa, Latin America, Asia, the Pacific, and all comparative topics (U.S./non-U. S,) to Teresa Meade, Department of History, Union College Schenectady NY 12308-2365. For more information see our website at: www-berks.aas.duke.edu 


\title{
History in Africa
}

\author{
A JOURNAL OF METHOD
}

Published annually since 1974

- Focuses on historiographical and methodological concerns:

- textual analysis and criticism

- historiographical essays

- the role of nonhistorical data in historical reconstruction

- the role of theory in historical investigation

- bibliographical essays

- archival reports

EDITORIAL CORRESPONDENCE: Manuscripts and other editorial correspondence should be directed to David Henige, Memorial Library, University of Wisconsin, Madison WI 53706. Phone 608-262-6397, Fax (608) 265-2754, email: henige@macc.wisc.edu

SUBSCRIPTION INFORMATION: History in Africa (ISSN 0361-5413) is published annually by the African Studies Association. For subscriptions, back issue and single issue orders, see below.

Mail to: History in Africa

African Studies Association

Emory University

Credit Union Bldg.

Atlanta, GA 30322 USA
Institutions in USA

Institutions surface outside USA

Institutions airmail outside USA

Individuals in USA.

Individuals surface outsideUSA.

Individuals airmail outside USA...

*Single issue price.
$\$ 43.00$

$\$ 45.00$

$\$ 48.00$

$\$ 25.00$

$\$ 27.00$

$\$ 37.00$

$\$ 35.00$

*Orders shipped 4th class (book rate) unless special arrangements are made. Within US, add $\$ 3.50$ for $1 \mathrm{st}$ item, $\$ 1.00$ for each additional item. Outside US, add $\$ 4.00$ for $1 \mathrm{st}$ item, $\$ 1.50$ for each additional item. Credit card orders may be faxed to (404) 329-6433.

Name

Address

City State Zip Country

METHOD OF PAYMENT CHECK , MONEY ORDER MCARD VISA CREDIT CARD \# SIGNATURE EXPIRY DATE $\$$ 


\section{ASA Annual Meeting Papers Collection 1993 - 1996 CD-ROM}

To mark the 40th Anniversary of the African Studies Association we are trying an exciting experiment. This year instead of releasing the Annual Meeting Papers Collection in photocopy, microfilm, and microfiche we are putting it on CD-ROM. Not only are we putting the 1996 papers on the CD-ROM, but we are packaging them together with the papers of the 1993, 1994, and 1995 Annual Meetings. Altogether that is 514 papers, close to 11,500 pages of scanning in all! In the past each annual collection was priced at $\$ 375$ per set, hardly something an individual could afford.

This Collection is so affordable (please see the next page for pricing) that we will no longer make these papers available as individual photocopies. Now every African Studies program, regardless of its size, can make this entire collection available to faculty and students for only $\$ 99.00$. That is almost a $75 \%$ savings over the price of yesterday's technology!

The Annual Meeting Papers Collection was started in 1971 when the ASA Archives-Libraries Committee took on the daunting task of assembling as many of the papers as they could find. What resulted was a collection of about one thousand papers from the 1960, 1965 - 1974 meetings. Since that time each year the Association has asked members to contribute papers to the collection. The annual collection has grown into one of the best sources of current thinking in African Studies available today. It is also a valuable collection from a historical point of view since it provides an accurate "snap shot" of the thinking of many leading Africanists in a given year.

The 1993 - 1996 Annual Meeting Papers Collection CD-ROM puts four years of Africanist scholarship at your fingertips. The CD-ROM is cross-platform and can be opened either with Macintosh or Microsoft operating systems, all the software needed is included on the disk.

We think that you will agree that the Collection is a remarkable set of papers and an absolute must for your personal library, not to mention a necessity for your institution's library.

The Collection is attractively priced and a $20 \%$ discount is available to ASA members. Members who have contributed to the 1993 - 1996 Collection will receive a $50 \%$ discount off the regular individual price of $\$ 65.00$. 


\section{ASA Annual Meeting Papers Collection 1993 - 1996 CD-ROM \\ ORDERING INFORMATION}

Institutions. $\$ 99$

Institutions (2ed or backup copy only with purchase of one at regular price). $\$ 50$

Institutions in Africa. $\$ 45$

Institutions in Africa (2ed or backup copy only with purchase of one at regular price).

Individuals (Non-Members). .$\$ 65$

ASA Members (with 20\% Discount)

Contributors to the Collection (with 50\% Discount).

SUB-TOTAL

Postage \& Handling

$\$$

First Class Mail to US \& Canadian Addresses (\$4.00 additional copies \$1.75)

Airmail to All Other Addresses (\$6.50 additional copies \$3.75)

TOTAL AMOUNT ENCLOSED OR CHARGED

US $\$$

Name

Email

Street Address

City State Postal Code

Payment: Personal orders must be accompanied by a check or money order payable in US dollars, or charged.

Charge my: Visa MasterCard

Card \# Exp.

Signature

AFRICAN STUDIES ASSOCIATION PRESS

Emory University/Credit Union Building

Atlanta GA 30322 USA 


\title{
ASA WOMEN'S CAUCUS
}

The Women's Caucus of the African Studies Association seeks to promote the study of gender within the various disciplines represented in the Association, ensure an active and representative role for women Africanists within the Association, and develop links between the Association and women in Africa.

DUES SCHEDULE

\section{WOMEN'S CAUCUS MEMBERSHIP}

SALARY

$\$ 30,000 \&$ above

$\$ 20,000$

up to $\$ 19,000$

Student

African Women in Africa

Institutions
DUES

$\$ 20$

$\$ 15$

$\$ 10$

$\$ 5$

FREE

$\$ 25$

\section{Women's Caucus Mentor Directory \\ Member \\ $\$ 8.00$ each \\ Non-Members \\ $\$ 10.00$ each}

Make checks payable to:

\author{
Margot Lovett \\ Department of History \\ Saddleback College \\ 28000 Marguerite Parkway \\ Mission Viejo, CA 92692
}




\begin{tabular}{|c|c|}
\hline $\begin{array}{r}\text { Visit the African } \mathrm{S} \\
\mathrm{We}\end{array}$ & $\begin{array}{l}\text { dies Association } \\
\text { ite }\end{array}$ \\
\hline \multicolumn{2}{|c|}{$\begin{array}{c}\text { http://www.sas.upenn.edu/African_Studies/ } \\
\text { Home_Page/ASA_Menu.html }\end{array}$} \\
\hline \multicolumn{2}{|c|}{$\begin{array}{l}\text { *Visit the African Studies Association Website for } \\
\text { information on ASA membership, ASA governance, and } \\
\text { information on the African Studies Association Press. } \\
\text { *The Tables of Contents for the following journals are also } \\
\text { available on the ASA website: } \\
\text { [At the main menu go to ASA Press and then to ASA Journals] }\end{array}$} \\
\hline African Studies Review & $\begin{array}{l}\text { Volume } 23 \text { (1980) through } \\
\text { Volume 40/2 (1997) }\end{array}$ \\
\hline History in Africa & $\begin{array}{l}\text { Volume } 1 \text { (1974) through } \\
\text { Volume } 24 \text { (1997) }\end{array}$ \\
\hline Issue & $\begin{array}{l}\text { Volume } 1 \text { (1972) through } \\
\text { Volume } 24(1996)\end{array}$ \\
\hline $\begin{array}{r}\text { African Studie } \\
\text { Emory U U } \\
\text { Credit Un } \\
\text { Atlanta, } \\
\text { (p) } 404-329-6410 \\
\text { email: africa }\end{array}$ & $\begin{array}{l}\text { sociation } \\
\text { rsity } \\
\text { 3ldg. } \\
0322 \\
\text { 404-329-6433 } \\
\text { ory.edu }\end{array}$ \\
\hline
\end{tabular}



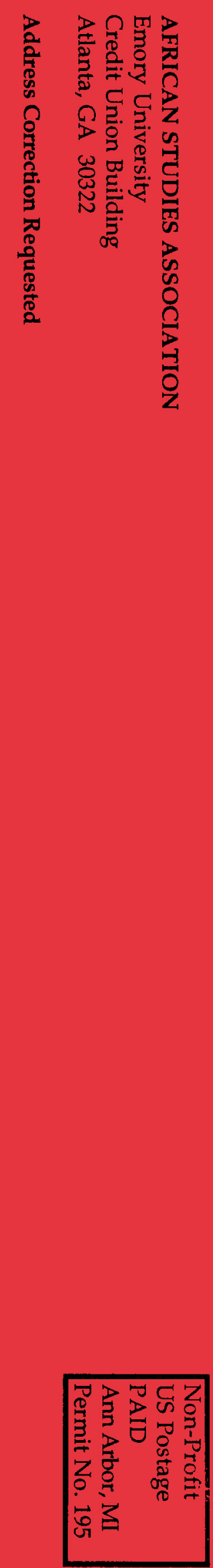